\title{
EL TOPOS SIMBOLISTA DE LA CIUDAD MUERTA EN LA TRADICIÓN LITERARIA EUROPEA Y ESPAÑOLA
}

\author{
Dorde Cuvardic García
}

\begin{abstract}
RESUMEN
En este artículo se realiza un exhaustivo recorrido por la representación de la ciudad muerta en la literatura europea y española fin de siglo, con especial interés en Rodenbach, en el caso belga, y en Azorín, en el español. Primero, se emprende una introducción por este topos, por el estado la cuestión crítico existente y por las razones de su eclosión en la literatura europea fin de siglo. En segundo lugar, se identifican las más importantes manifestaciones de este topos en la literatura europea, con especial incidencia en Brujas la muerta (1892), de Georges Rodenbach, que inició su auge en el simbolismo finisecular. También se exponen las más importantes manifestaciones de la ciudad muerta en la literatura de la Generación del 98, como es el caso, principalmente, de Azorín (Toledo, Yecla, Lantigua, Villena), de Baroja (Toledo, Alcolea del Campo) y Machado (Soria). Por último, se determinan las ciudades muertas en otros autores de la literatura española y latinoamericana, más allá de la Generación del 98: Vetusta, en La Regenta, de Leopoldo Alas (Clarín) o Ypres (en las crónicas de Guerra de Enrique Gómez Carrillo).

Palabras clave: Ciudad muerta, topos, literatura comparada, literatura española, literatura belga,
\end{abstract} Azorín, Rodenbach.

\begin{abstract}
In this article, we make an exhaustive survey of the representation of the dead city in European and Spanish literature of the end of the century, with special interest in Rodenbach of Belgium and Azorin of Spain. First, we introduce by this literary convention, the current state of this critical issue and the reasons for its emergence in European literature at the end of the century. Second, we identify the most important manifestations of this motif in European literature, with special emphasis on The Dead City of Bruges (1892), by Georges Rodenbach, who initiated the rise of this motif in the symbolism of the turn of the century. Also, we identify the most important manifestations of the dead city in the literature of the Generation of 98 , which is principally the case of Azorin (Toledo, Yecla, Lantigua, Villena), Baroja (Toledo, Alcolea del Campo) and Machado (Soria). Finally, we discuss the dead cities of other authors of Spanish and Latin American literature, beyond the 98 Generation: Vetusta, in The Regent's Wife, Leopoldo Alas y Ureña (also known as Clarín) or Ypres (in The Chronicles of Enrique Gómez Carrillo).
\end{abstract}

Key words: Dead city, topos, comparative literature, Spanish literature, Belgian literature, Azorín, Rodenbach.

Dr. Dorde Cuvardic García. Profesor de la Escuela de Filología, Lingüística y Literatura. Universidad de Costa Rica. Correo electrónico: dcuvardic@yahoo.es

Recepción: 12- 04- 2012

Aceptación: 25- 04- 2012 


\section{Introducción}

A finales del siglo XIX y comienzos del XX se dio un periodo de crisis de los valores de la modernidad (progreso, etc.) en el mundo intelectual, literario y artístico occidental. En este ambiente 'espiritual', en el que participaron el simbolismo y el decadentismo, la ciudad, símbolo de la enfermedad moral de la modernidad, también queda afectada por los procedimientos y los valores ideológicos de estas últimas estéticas. Por toda Europa surgen novelas, poemas e incluso textos pictóricos sobre la ciudad muerta. Entre las novelas más relevantes, por ejemplo, se encuentran Brujas la muerta (1892), de Georges Rodenbach y Muerte en Venecia (1911) de Thomas Mann. En la ópera, podemos mencionar Die Tote Stadt (1917), de E.W. Korngold, con libreto de Paul Schott, así como, décadas después, la ópera de 1973 del mismo nombre, de Benjamin Britten, basada en la novela de Thomas Mann.

El topos que nos ocupa implica la representación simbólica de ciudades reales reconocibles, por lo que deben excluirse la ciudad fantástica -La ciudad sumergida, de Edgar Allan Poe- y la ciudad arqueológica (Lozano Marco 2000: 13-4).

El topos de la ciudad muerta también se aclimató al suelo español. Lili Litvak destaca este hecho, al precisar que, como "proveniente del simbolismo belga tuvo importante resonancia en España. Era una reacción contra el industrialismo finisecular y respondía al estímulo de Schopenhauer" (Litvak 2011). Pero más que crítica de la industrialización es de los valores de la cultura de la modernidad. En Azorín, por ejemplo, la construcción de la ciudad o pueblo muerto o abúlico se relaciona directamente con el rechazo hacia los valores de la ciudad moderna.

En España se da una resignificación parcial de este topos frente a sus versiones transpirenaicas. En el país peninsular, adquiere un significado ambivalente. En ocasiones, supone una crítica, no tanto de la industrialización (de escasa raigambre en España, hasta el momento), sino más bien de una modernidad -más o menos acelerada- que destruía a marchas forzadas un sistema de vida y unos valores tradicionalistas todavía existentes en este país (arrinconados cada vez más en los pueblos). En estos casos, la ciudad muerta (o el pueblo abúlico, como habría que llamar más pertinentemente a este espacio simbólico en España) adquiere una valencia positiva. En otras oportunidades, la ciudad muerta o el pueblo abúlico, supone, en tono regeneracionista, una crítica contra la pervivencia de unos antivalores tradicionalistas (el espíritu cainita) que la modernidad no ha conseguido eliminar del espacio rural (con sus ciudades provincianas y sus pueblos).

Podemos afirmar que la ciudad o el pueblo abúlico -indistintamente utilizaremos ambos términos- es la reescritura española del topos europeo de la ciudad muerta. Es un concepto que he acuñado, pero que interpretativamente es tan productivo como otros que han propuesto los autores de la Generación del 98 para hablar de una realidad similar a la que estudiamos en el presente caso, como son Andalucía trágica, de Azorín ${ }^{1}$, o España negra, de Darío de Regoyos o José Gutiérrez Solana².

A diferencia de la abulia nacional, entendida como enfermedad colectiva diagnosticada por los intelectuales del 98 (Jurkevich 1992; Shaw 1998), la contribución española al topos europeo de la ciudad muerta (los pueblos abúlicos y su configuración estética) ha sido muy poco investigada, vacío que pretende llenar el presente artículo. Asimismo, analizar el topos de la ciudad muerta nos permitirá insertar las preocupaciones filosóficas y estéticas de la Generación del 98 en los planteamientos filosóficos y estéticos 
de la crisis fin de siglo a escala europea, un proyecto académico que comenzó en los años sesenta del pasado siglo.

El análisis de la representación de los pueblos abúlicos permite contribuir al estudio de España como problema en la Generación del 98, con particular atención en las novelas de Azorín. La economía, la convivencia ciudadana y el estilo de vida de los pueblos abúlicos son indicadores del declive económico y moral colectivo de la nación española, que tanto analizó este último grupo de intelectuales. Es decir, el tema que estudiamos tiene carácter identitario, como explica Vigneron (2009a: 4) al referirse a la pertinencia del sintagma acuñado por Inman Fox (la invención de España, que procede del libro del mismo nombre).

No existe un abundante estado de la cuestión sobre el topos de la ciudad muerta, tanto de la europea como estrictamente de la española. El estudio clásico es la investigación de Donald Flanell Friedman, titulada The Symbolist Dead City. A Landscape of Poesis, publicada en 1990. Analiza la metáfora de la enfermedad en las representaciones literarias y pictóricas de la ciudad flamenca de Brujas. También estudia el principal tipo social de esta ciudad muerta: la monja, cuya vida monacal la vincula con la negación de la individualidad y del mundo; asimismo, expone cómo el poeta simbolista asume a la monja como una proyección de su propio programa estético. Además, entiende que este espacio es propicio para la alucinación y la ensoñación; es un ambiente misterioso, rebosante de irrealidad, desmaterialización y estetización, alejado de las contingencias de la vida moderna. Por último, analiza la presencia del topos de la ciudad muerta en la pintura simbolista de la época, sobre todo de Ferdinand Khnopff. Podemos observar a través de una primera comparación de la ciudad muerta en la literatura belga y en la española que en la primera su simbología se encuentra más vinculada al inconsciente, a la irracionalidad, a la esfera de los sueños, mientras que en el caso español se vincula parcialmente al nihilismo filosófico finisecular (el escritor busca en la ciudad muerta un reposo a sus luchas infructuosas frente al mundo) y el análisis sociológico, entre crítico y elogioso, a un sistema de vida tradicional que se está perdiendo.

Desde un análisis centrado en la poesía y desde el comparatismo literario, García Pérez (2008), en el artículo "Interpretaciones del tópico de la ciudad muerta en la poesía española y francesa", analiza sus reformulaciones o reescrituras en el ciclo "Paisajes de la ciudad" (Payags de ville), del libro El reino del silencio (1891), de Georges Rodenbach; el soneto "Ville Morte", del libro En el jardín del infante (1893), de Albert Samain; y el poema "Ciudad Muerta", del libro Las horas que pasan (1902), de Francisco Villaespesa; así como las interferencias existentes entre el tópico de la ciudad muerta y el del jardín, presente este último en "Jardín Gris", del libro Alma, de Manuel Machado. Analiza los orígenes del sintagma ciudad muerta en la práctica literaria francesa y española, enraizados más que todo en la representación de las ciudades desaparecidas recuperadas por la arqueología. Por su parte, en su análisis detenido del poema de Villaespesa destaca sus fuentes eclécticas (García Pérez 2008: 129).

Shaw (1997), en su clásico libro sobre la Generación del 98, no se hace eco de la presencia de la ciudad muerta en el capítulo Azorín: el redescubrimiento de la tradición, dedicado al escritor alicantino (topos con el que supuestamente debería estar vinculado), aunque en el prólogo al libro, fechado en 1977, donde declara la participación de la Generación mencionada en las preocupaciones estéticas y filosóficas fin de siglo a escala europea, se podría haber abrigado en principio alguna expectativa sobre el desarrollo de este topos en la prosa azoriniana. Shaw sólo declara que en las obras del escritor alicantino "encontramos largas series de descripciones de lugares - ciudades o paisajes- con su atmósfera de desolación, quieto 
inmovilismo, aridez y miseria. Lo que sugieren a Azorín son las características negativas de la mentalidad española" (1997: 221). Un análisis más detenido nos permitirá comprobar que los valores intrahistóricos positivos, aquellos que deben quedar como legado para el futuro, también forman parte de estas descripciones.

Por su parte, la edición crítica de Diario de un enfermo (1901), de Azorín, realizada por Francisco J. Martín (2000), se centra en analizar el simbolismo decadentista de esta novela, estética de la que participa de la ciudad muerta. Sobre todo interesan las explicaciones que sobre este último topos ofrece este crítico en la nota a pie en las páginas 208-210, sobre los valores positivos y negativos que comporta, desde el punto de vista de la voluntad schopenhaueriana, y que se citarán en las próximas páginas.

Anke Glebel, en su análisis de la Brujas la muerta (1892), de Georges Rodenbach, vincula la particular sensibilidad y experiencia sensorial de su protagonista, Hugues Viane, que realiza frecuentes paseos, con la apreciación estética de la ciudad muerta. Viudo inconsolable, Viane busca en la ciudad amortajada un estado de ánimo similar al suyo. En esta novela, organizada a partir del recuerdo de la esposa muerta, vemos una actualización del mito de Orfeo, como bien se ocupó de analizar Friedman (1990: 135-171) en el ámbito de la tematología, ya que hablamos de un mito organizado a partir del duelo de un hombre hacia su esposa muerta, duelo que tratará de mantener a partir de la conservación fetichista de sus objetos (cabellos, ropas).

No sólo Glebel relaciona la representación de la ciudad muerta con la mirada de un personaje peripatético solitario que proyecta su estado de ánimo en el espacio urbano, proceso que tiene su precedente mas cercano, en su función ensoñadora, en el vagabundeo filosófico en la naturaleza, perspectiva típicamente romántica. Pike también ha señalado que "[d]urante el siglo XIX la palabra ciudad estuvo representada cada vez más en la literatura como refracción inestable de una conciencia individual, más que como un objeto fijo en el espacio" (1981: 71). En un proceso que se da gradualmente a lo largo del siglo XIX, la mirada panorámica sobre la ciudad queda arrinconada a favor de la mirada desde la calle, que podemos denominar, en términos amplios, como mirada del flaneur, como la de Vianes en sus paseos por Brujas. Debe destacarse, en todo caso, que algunas de las representaciones de la ciudad muerta, como sucede en la representación de las ciudades y pueblos abúlicos de Azorín, pueden darse también desde la mirada panorámica (desde un monte cercano, o desde lo alto de un edificio).

El clásico estudio de Hans Hinterhäuser sobre el tópico, y que constituye un capítulo de su libro Fin de siglo: Figuras y mitos (1980), se ocupa de investigar la imagen de las tres ciudades muertas paradigmáticas a escala europea: Brujas, Venecia y Toledo. Es, más que todo, un estudio descriptivo, que no aporta novedosas claves interpretativas.

En el ámbito de la literatura española, Lozano Marco (2000: 24) ha explorado la presencia de la ciudad muerta. Cuando declara que en su representación no interviene el determinismo naturalista, su afirmación debe matizarse. Considera que los escritores españoles que se ocupan de este topos no realizan un análisis ambiental sociológico, ya que no asumen la ciudad o el pueblo muerto como medio para analizar la influencia de este espacio en el individuo, es decir, los condicionamientos sociales que explican su conducta. Para Marco, en las construcciones españolas de la ciudad muerta más bien hablamos de correspondencia entre estados de ánimo. Si bien es cierto que esta equiparación o correspondencia, que pertenece a la estética simbolista, opera en el personaje de Antonio Azorín y aquellos intelectuales que se retiran a los pueblos, desencantados del compromiso político (ven en el espacio humano una 
equiparación simbólica con su propio estado de ánimo), los habitantes de las ciudades muertas españolas, en cambio, pueden quedar sometidos al análisis del determinismo naturalista (véase, por ejemplo, Las confesiones de un pequeño filósofo, de Azorín).

Como vemos, los estudios sobre la presencia del topos de la ciudad muerta en las literaturas europeas se ocupan sobre todo del caso belga. Y por lo que respecta a la literatura española, no existe todavía un estudio sistemático y abarcador sobre la construcción del topos de la ciudad muerta en la novelística de Azorín y en la escritura de otros autores, aspecto que quiere llenar el presente artículo.

Al realizar una evaluación general del estado de la cuestión, concluimos que este topos ha sido analizado en la literatura transpirenaica y en el marco del comparatismo interartístico, aunque no desde el arte y la literatura de la España de fin de siglo.

\section{El estudio de la ciudad muerta como topos literario}

La investigación del topos de la ciudad muerta se enmarca en el ámbito del estudio de la tópica literaria desde una óptica comparatista. Se podría discutir si la ciudad muerta es un tema, un motivo o un topos. Elegimos este último término, por cuanto destaca, frente a los otros, la capacidad de situar un contenido literario - una descripción urbana, en este caso- en una expresión lingüística más o menos fija. Por ejemplo, en el tópico del Ubi sunt siempre se formula la pregunta retórica sobre el paradero de las glorias políticas del pasado. De la misma forma, hemos de esperar en la expresión del topos de la ciudad muerta la aparición de lexemas como silencio, vacío, la descripción de similares tipos sociales... Compartimos el punto de vista de Beller cuando reclama "el concepto de tópico literario para aquellos fenómenos tópicos que se mantienen constantes en su estructura, aunque la tradición atestigüe también variantes"3 (Naupert 2001: 109). En su caso, la ciudad muerta se puede descubrir tanto en un solo párrafo o estrofa, como en el capítulo de una novela o en todo un poema.

En el estudio de las novelas, siempre se ha menospreciado la funcionalidad de la descripción frente a la narración. Podemos, sin embargo, demostrar la importancia radical de las descripciones en el discurso novelístico, como sucede en las representaciones de las ciudades muertas: 'amueblan' el mundo posible en el que los personajes desarrollan sus acciones y otorgan verosimilitud a este último. Podemos, en consecuencia, deconstruir la dicotomía descripciónnarración y otorgar un papel relevante a su desempeño funcional en el género novelístico. La descripción pasa a ocupar una función importante en el 'sistema literario novelístico'.

La ciudad muerta es un espacio general tipificado (Naupert 2001: 125), que se encuentra ejemplificado en distintas ciudades paradigmáticas: Brujas, Toledo, Venecia. Es un cronotopo (Bajtín) que cuenta con sus particulares relaciones espacio-temporales: el espacio es relativamente pequeño (una ciudad), mientras que la temporalidad es relativamente amplia (la larga decadencia socio-económica de una cultura, de una sociedad), incluso podemos afirmar que se caracteriza también por la atemporalidad (el 'estancamiento' de la ciudad -como marasmo moral y económico-, la pervivencia de las tradiciones ancestrales...). Un espacio singular literario ofrece como tema de investigación, por ejemplo, "La representación de París en...", mientras que un espacio general, de connotaciones simbólicas, como es el caso que nos ocupa, es "La representación de la ciudad muerta en ...".

Ya Bajtín tomó conciencia de las relaciones espacio-temporales específicas que se pueden dar en un espacio de este tipo en lo que denominó el cronotopo de la pequeña ciudad 
de provincias, mediante el ejemplo de Madame Bovary (1865), de Flaubert, cuya vida se caracteriza por la rutina:

\begin{abstract}
Tal ciudad es el lugar del tiempo cotidiano cíclico. Aquí no hay sucesos, sino sólo «hechos frecuentes» que se repiten. El tiempo carece aquí de decursar histórico progresivo, se mueve por círculos estrechos: el círculo del día, de la semana, del mes, de toda la vida. [...] De día en día se repiten las mismas acciones cotidianas, los mismos temas de conversaciones, las mismas palabras, etc. Es éste el tiempo cíclico de la vida cotidiana. [...] Los rasgos de este tiempo son simples y groseramente materiales y se han unido sólidamente a las localidades cotidianas: a las casitas y habitaciones de la ciudad, a sus calles soñolientas, al polvo y las moscas, a los clubes, billares, etc. El tiempo aquí carece de acontecimientos y por ello parece casi detenido. Aquí no ocurren ni «encuentros» ni «separaciones». (1986: 457-458)
\end{abstract}

El tiempo aparece solidificado, materializado, en los espacios simbólicos de la pequeña ciudad provinciana. Así, por ejemplo, una iglesia expresa -a través de la erosión de su piedra, por ejemplo- los siglos que han pasado desde su construcción: la noción de progreso histórico queda anulada. Las famosas casas tradicionales de los artículos y las novelas de Azorín, por ejemplo, con todos sus artilugios tradicionales, materializan la pervivencia del pasado en el presente. En todo caso, los pueblos y las ciudades abúlicas que describen los narradores de las novelas y ensayos de Azorín no sitúan necesariamente sus coordenadas temporales a finales del siglo XIX e inicios del XX. De hecho, en ocasiones la temporalidad responde al siglo XVII (primera parte de El alma castellana), al XVIII o al XIX (primera mitad de este siglo, en Doña Inés). Y aunque cronológicamente queden situadas a finales del XIX e inicios del XX, social y culturalmente se ubican en el XVII o XVIII.

Las tradicionales metáforas maestras que organizan la representación de la ciudad son la máquina, el bazar, el organismo y la jungla (Langer 1984). La ciudad muerta pertenece al paradigma de la ciudad organismo, en este caso en descomposición o, con mayor precisión, embalsamada, amojamada. La simbología de la ciudad muerta pertenece al legado del Romanticismo: de la misma manera que el alma atormentada romántica proyecta su alma en la naturaleza circundante y reviste a esta última de atributos humanos (el objeto -es decir, la naturaleza- se convierte en sujeto), asimismo en las manifestaciones culturales de la ciudad muerta el alma 'amojamada', en crisis, de los narradores, por lo general artistas y escritores, proyectan su personalidad en un espacio que identifican como moribundo ${ }^{4}$ y seguidamente lo consideran como analógico a su propio estado de ánimo.

Es preciso destacar que, como topos, la ciudad muerta concentra una gran carga simbólica. El símbolo, cuyo origen muchas veces es arcaico, es fácilmente ubicado en relación al contexto semiótico circundante (Lotman 1996). Esto sucede con el topos de la ciudad muerta, identificable en secciones de novelas que utilizan la modalidad discursiva de la descripción.

No debe olvidarse, por otra parte, que la 'ciudad muerta' forma parte de la cultura rural. En la literatura española, por ejemplo, las ciudades o pueblos abúlicos (la peninsularización del topos de la ciudad muerta europea), deben quedar situados en un espacio mayor: el paisaje castellano (el castellano-manchego, e incluso el de las comarcas 'interiores' de regiones mediterráneas como la valenciana y la alicantina). Y la reflexión de Azorín sobre el paisaje castellano (y del resto de los autores de la Generación del 98), así como sobre los pueblos abúlicos, se inserta en un proyecto mayor, el de pensar sobre 'España como problema'. En el caso particular de Azorín, señala Vigneron que "el escritor se propone reflexionar, a través de la percepción del paisaje, sobre las condiciones de la modernidad intelectual, cultural y artística de la España de entre siglos" (2009b: 123). 
Como primera aproximación al significado de la ciudad muerta, ofrecemos las reflexiones de Martín, quien sintetiza la estética y la ideología de este topos en su edición de Diario de un enfermo (1901), de Azorín. Considera que la imagen de esta ciudad implica

\begin{abstract}
silencio, reposo, quietud, melancolía, tristeza, atracción por la vida retirada de los conventos, el sonido de las campanas de las iglesias, etc. [...]. Frente al industrialismo moderno de las metrópolis, la ciudad muerta se levanta como símbolo de la incapacidad del artista para vivir la escisión entre vida y arte que representan las grandes ciudades [...] lugar de un aprendizaje superior al que el artista llega en peregrinación en el intento de sanar del mal du siècle. [...] es la materialización de una enfermedad del alma, una suerte de hemorragia interna de la voluntad de vivir, una especie de consciencia (voluptuosa) del cimetière intérieur del sujeto. Y sin embargo, esta vida de provincias, con su gusto por las pequeñas cosas y los detalles insignificantes (ámbito estético en el que se despliega la ética del reposo), no se eleva a símbolo positivo capaz de abrir una brecha en la crisis vital (artística e intelectual) del sujeto moderno. La ciudad muerta representa también la otra cara de la crisis del nihilismo: es el mal de province, la angustia del mundo provinciano, el gris de los días siempre iguales, la noia y el spleen de los domingos vacíos. [...] en ningún caso, la ciudad muerta se propone como símbolo de retorno al pasado; [...] no puede haber futuro para las ciudades muertas, pues su presente anodino lo excluye. (2000: nota 101, 208-210)
\end{abstract}

Martín destaca la importancia que revistió el topos de la ciudad muerta como símbolo de la situación marginal que ocupa el campo literario en el sistema económico capitalista de finales del siglo XIX. Expresa la derrota, ya definitiva, que tienen los valores estéticos en el mundo moderno, capitalista, urbano. El intelectual no soporta la separación entre 'vida y arte' que se promueve en la ciudad, que le niega su función 'letrada', y este último se retira al espacio rural tradicional para soportar este dolor existencial. La ciudad muerta es la mortaja de la que se reviste el artista, una vez que ha sido expulsado de la élite política y cultural de la modernidad (de ahí, en las novelas de Azorín, la abundancia de intelectuales que viven en un sencillo retiro en las ciudades y pueblos abúlicos, una vez que se alejaron desencantados de la cultura de masas de las ciudades).

Por lo demás, Martín expresa otra semántica importante de este topos. Si la muerte es el destino implacable de la sociedad y del sujeto individual, la representación del topos de la ciudad muerta expresará la conciencia que tiene el individuo desesperanzado de haber encontrado su equivalente en un espacio social inerte, quieto, amortajado...

¿En qué se distingue la ciudad muerta del simbolismo (actualizada tanto en prosa como en poesía) del topos de las ruinas (principalmente desarrollado en poesía, del Renacimiento al Romanticismo)? Friedman (1990: 128-9) considera que, de los dos usos de la poesía de las ruinas en la poesía francesa, el moral (símbolo de la fragilidad -mortalidad- de la vida) y el pintoresco (su asimilación con la naturaleza, por lo general humanizada, en este caso por medio de la arquitectura), el simbolismo belga realiza un uso del topos más cerca del primero, que expresa la degradación (ruination) del alma humana, su enfermedad espiritual, la interiorización subjetiva de un mundo detenido, en 'ruinas'. No hablamos estrictamente de una ciudad en ruinas, muerta, vacía de todo elemento humano, sino de una ciudad moribunda, habitada sobre todo por individuos de avanzada edad.

En la literatura europea, el topos de la ciudad muerta es clara manifestación de la corriente estética del simbolismo. Como sabemos, este proyecto estético asume que el símbolo no busca definir, sino sugerir, aludir. En los textos narrativos y poéticos del simbolismo literario de la ciudad muerta se estructura una correspondencia o analogía entre el estado de ánimo del sujeto protagonista y el de la ciudad.

¿Ocurre lo mismo con su manifestación en los autores de la Generación del 98 ? Sí, si prestamos atención a los procedimientos simbolistas que utilizó la escritura de esta 
generación. Ya no alude a la ensoñación y la alucinación, desde la ideología más introspectiva del simbolismo belga. La ciudad muerta, en el caso español, reviste una connotación más política: es símbolo que condensa el marasmo, la falta de voluntad del 'alma castellana', tanto del intelectual como del pueblo, y también símbolo de los valores tradicionalistas que, si son puestos al servicio de la regeneración espiritual de la Nación, la podrán encaminar a un nuevo florecimiento económico. De esta manera, podemos contribuir a la inserción de la Generación del 98 en las corrientes estéticas fin de siglo, proyecto que se viene perfilando desde los años sesenta.

\section{La ciudad muerta en la tradición de la literatura simbolista europea}

La más conocida representación de la ciudad como topos simbolista, y el texto que contribuyó a proyectarlo como modelo a seguir, es la novela corta Brujas la muerta (1892), del escritor belga Georges Rodenbach. Con excepción de algunos pasajes descriptivos, cuya intención es 'ambientar' el carácter melancólico de la ciudad, en la mayor parte de las ocasiones se describe la ciudad como espacio psicológico compatible con el estado de ánimo del protagonista, el viudo Hugues Viane.

El narrador no sólo establece algunas generalizaciones sobre la ciudad como personificación que se equipara, corresponde o tiene analogía con el estado de ánimo del ser humano, sino que también expresa la posibilidad de que la atmósfera urbana condicione o sea factor determinante del estado de ánimo del sujeto: "Sobre todo las ciudades tienen una personalidad, un espíritu autónomo [...]. Toda ciudad es un estado de ánimo y, apenas moramos en ella, este estado de ánimo se comunica, se propaga en nuestro interior como un fluido que se inocula" (Rodenbach 2011: 81). ¿Cuándo se propaga el estado de ánimo urbano al estado psicológico del sujeto humano? En aquellos momentos en los que el viudo Hugues Viane desarrolla el proceso del luto por su esposa muerta, durante sus largas caminatas... En estos casos, la atmósfera mortuoria de la ciudad contribuye a profundizar la melancolía de su luto. Dejamos de lado aquellos momentos en los que Viane llega a transferir los rasgos de su esposa a una actriz que encuentra un día en la calle, ya que en estas ocasiones la ciudad, Brujas, pierde, a los ojos del protagonista, su condición de ciudad mortuoria...

Como hemos sugerido en los párrafos precedentes, se pueden discriminar dos tipos de relaciones psicológicas entre Brujas y el protagonista. La primera de ellas se caracteriza por la analogía o correspondencia, por la equiparación entre el estado de ánimo de Hugues Viane y la ciudad de Brujas: en este caso, el viudo y la urbe comparten el 'luto'. Concuerdo con Gorceix (1992: 19-23) en definir la Brujas la muerta como novela de la analogía. De hecho, Viane decide residir en esta ciudad, que había visitado en vida de su esposa, porque considera que es un buen entorno ambiental que protegerá su luto: no hay fricción entre el estado de ánimo de la ciudad y el suyo propio. Lo que busca es el mayor ajuste posible entre el mundo objetivo y su propia subjetividad:

¡Y qué triste era Brujas cuando declinaba el día! ¡La quería así! La había escogido precisamente por su tristeza [...] había recordado Brujas y había tenido la intuición inmediata de que debía establecerse allí en lo sucesivo. Una ecuación misteriosa se imponía. A la esposa muerta tenía que corresponderle una ciudad muerta. Su gran duelo exigía tal decorado. (Rodenbach 2011: 17)

En la atmósfera de Brujas, Viane consigue conservar 'viva' la memoria de su esposa. La recuerda al reconocerla en la atmósfera urbana: "encontraba de nuevo a lo largo de los canales su rostro de Ofelia, escuchaba su voz en la melodía aguda y lejana de los carillones. [...] Brujas 
era su muerta. Y su muerta era Brujas" (Rodenbach 2011: 18). En estas circunstancias, Viane establece una relación de identidad, y no de simple semejanza, entre la ciudad y su esposa.

Las ciudades muertas son ciudades donde impera el rito católico (Brujas, Venecia, Toledo). Este topos no se concreta en ninguna ciudad protestante. Las campanas, que se describen en diversas ocasiones, como sucede durante el desarrollo de la procesión de la Santa Sangre ${ }^{5}$, connotan una ideología de recogimiento y respeto hacia los símbolos de la religión católica en consonancia con los ritos cotidianos y la veneración que Hugues Viane otorgaba a los 'fetiches' que le permitían conservar, con altibajos, la memoria de su esposa muerta.

El segundo tipo de relación psicológica entre Brujas y Hugues Viane se caracteriza por la transformación que el ambiente psicológico de la ciudad llega a operar sobre el estado de ánimo del protagonista (ya no hablamos de una relación de simple equiparación entre estados de ánimo). Para Viane, cuando desaparece progresivamente el hechizo hacia la actriz de teatro, la ciudad le inculca sentimientos de 'culpa' por haber 'mancillado' el recuerdo de su esposa muerta, por transferir en otro sujeto la identidad de la persona amada desaparecida:

\footnotetext{
la Ciudad, con su rostro de creyente, le reprochaba, insistía. Oponía el modelo de su propia castidad, de su estricta fe.../ Y las campanas mostraban su connivencia, mientras él seguía errando cada noche sumido en una angustia creciente, donde se mezclaba el sufrimiento de amar a Jane, la nostalgia de la muerta, el miedo a su pecado y a la condena posible... (Rodenbach 2011: 90)
}

Ante la posibilidad próxima de perder a Jane, la 'doble' de su esposa muerta, Hugues Viane siente cada vez más el peso de la soledad, que se concentra en la presión psicológica ejercida 'por' las campanas y las altas torres de la ciudad -siniestras, amenazantes- en su estado de ánimo. Asimismo, cuando siente celos ante una posible infidelidad de Jane y la acecha en su deambular callejero, se representa la ciudad como una entidad hostil. En estas últimas ocasiones, se encontraba "fustigado por la medianoche de los carillones, por las lloviznas incesantes del Norte" (Rodenbach 2011: 95). El escenario de sus vagabundeos es desolador: "nieve fundida, barro, cielos nublosos, fin del invierno, desoladora tristeza de las cosas..." (Rodenbach 2011: 95).

No sólo en la prosa de Georges Rodenbach aparece el topos de la ciudad muerta, sino también en su poesía. Un poema como "Domingo" incorpora muchos objetos, ritos y valores que ya hemos apreciado en Brujas la muerta y que podemos encontrar también en la prosa de Azorín: "Triste tarde inverniza, callada y dominguera / En el mudo letargo de pueblos provincianos, / En la que las veladas, inconsolables, giran / Solitarias, cual pájaros de hierro, en los tejados!" (Rodenbach 1930: 38). ¿Qué atributos puede compartir la primera estrofa con las descripciones de las novelas de Azorín? La tristeza, el letargo (la somnolencia), la calma, la soledad... El ambiente opresivo de los pueblos de los pueblos abúlicos españoles encuentra su equivalente en el tedio invernal de la ciudad flamenca: " $¡ V a$ flotando en el viento no sé qué triste angustia!" (Rodenbach 1930: 38). El segundo párrafo identifica transeúntes dispersos. En la ciudad muerta nunca se observarán multitudes: "Escasos transeúntes se ven por las aceras: / Curas, mozas del pueblo con negros capuchones, / Y beguinas que vuelven calladas de la iglesia. / Hay rostros de mujeres pegados a los vidrios / Contemplando el vacío, el silencio y la calma" (Rodenbach 1930: 38). También en la novelística de Azorín se observan a curas y beatas, camino de las iglesias, como siluetas que forman parte de la escenografía.

Un tópico clásico de la ciudad muerta es la descripción de los edificios del poder eclesiástico y temporal, cuyos vetustos objetos, olvidados, indican la desaparición del uso que una vez tuvieron, como se observa en el poema mencionado de Rodenbach: 


\begin{abstract}
Y por las entreabiertas cortinas ventanales, / En los grandes salones de los nobles palacios / Pueden verse en el fondo de viejos gobelinos / Retratos familiares entre oros apagados. / -Jubón de terciopelo y gorguera de encajes / Y su blasón pintado a un costado de pecho- / Que miran a lo lejos cintilar una estrella / Y dormir en pesado silencio. / Todos estos palacios deslucidos y solos, / Guardan dentro el recuerdo de la muerta Edad Media. (1930: 38-39)
\end{abstract}

En resumen, en este poema se presta atención a la ciudad muerta, es decir, a la ciudad o pueblo provinciano, a su soledad, al silencio, a la escasez de transeúntes, y a los palacios, vacíos y adormecidos, testigos de un pasado de esplendor imperial.

Otros poemas de Rodenbach incorporan la atmósfera de la ciudad muerta. El espacio público crepuscular, mortecino, se ofrece en "Paisajes de la ciudad". La casa 'adormecida' y 'amortajada', como la misma ciudad provinciana donde se sitúa, se perfila como símbolo en el poema "La casa paterna", donde se confronta la carencia de vida del presente enunciativo y la vitalidad familiar pretérita: "Los muebles viejos, familiarizados (sic) / Gastados en su estática actitud / Añoran el encanto de los trajes / En los salones llenos de quietud" (Rodenbach 1930: 22).

Esta misma intencionalidad, enraizada en la añoranza, con el pasado entendido como ensoñación personal, también estructura el poema "La vida de las habitaciones". Por su parte, "Paseo" representa esta práctica, realizada por el yo lírico en la ciudad provinciana (utiliza el nosotros inclusivo, al incorporar al lector en su experiencia), así como en sus alrededores, al caer la tarde. Los paseos vespertinos, que expresan quietud e indiferencia hacia la velocidad del progreso, también constituyen una práctica común en los protagonistas de las novelas de Azorín. El retiro frente a la sociedad se expresa en el poema "Solo". En este último caso, la experiencia, genéticamente descrita, se puede equiparar a la del viudo Hugues Viane de Brujas la muerta, en su ansia de retiro: "Vivir como en exilio, vivir sin ver a nadie, / Solo en el abandono de una ciudad que muere / Sin escuchar más voces que el sollozo del órgano / O la voz del beffroi [campana principal de una iglesia] que de lo alto viene" (Rodenbach 1930: 28). El poema "Beguinado flamenco" nos ofrece la descripción y la atmósfera de este espacio de retiro espiritual, habitado por mujeres seglares dedicadas a Dios (principal distinción con el convento de monjas). La tristeza del espacio público mortecino de Brujas se expresa en "Viejos muelles", ciudad que desde el siglo XV no tiene salida al mar. La lluvia como símbolo de ensoñación nostálgica, dolorosa, aparece en el poema del mismo nombre. La ensoñación es un tema que permite distinguir a la ciudad muerta española de la flamenca. Además, también a la ciudad muerta española, a diferencia de la belga, la caracteriza la ausencia del agua, como símbolo del amortajamiento existencial, que en el caso de Rodenbach no sólo aparece en el poema "La lluvia", sino también en las aguas detenidas de los canales de Brujas de "El corazón del agua", que no solamente resguardan, los esplendores de la ciudad, sino los recuerdos personales de cualquier persona sumida en el luto o la añoranza. En "El silencio", este valor simboliza la soledad de los cuartos vacíos, aunque también está dedicado al sonido de los carillones y, al final del poema, el yo-lírico canta una elegía a la urbe adormecida: "¡La ciudad está muerta, irreparablemente! / Murió de lenta anemia y secreto tormento, / Ha muerto de día a día del tedio de estar sola...." (Rodenbach 1930: 56). A las campanas de las iglesias, el símbolo más paradigmático de la ciudad muerta, también se dedican los poemas "Las campanas" y "Carillón".

Poco conocidas son dos novelas belgas sobre el tema, En la ciudad muerta (1905), de Franz Hellens, y La canción del carillón (1911), de Camille Lemonnier. Expresa Friedman (1980: 74) que la visión de la ciudad muerta es, en ambas novelas, en términos semánticos, radicalmente opuesta: la Gante de la novela de Hellens se representa como un 
infierno; la Brujas de Lemonnier, como un paraíso. Como vemos, Brujas no es la única ciudad belga que se representa desde la ciudad muerta, la gran contribución de esta nación a la literatura simbolista europea.

Italia forma parte de la tradición de la ciudad muerta, tanto por la representación de las urbes italianas como ciudades muertas (el caso más representativo es Venecia, por autores extranjeros) como por la elaboración de este topos por los mismos escritores italianos. Gabriel D’Annunzio desarrolla este topos en la novela El fuego (1900).

En la novelística alemana, en La Muerte en Venecia (1911), de Thomas Mann, la decadencia de la ciudad italiana simboliza el declive del espíritu creativo y las dudas nihilistas de su protagonista, el escritor Aschenbach (literalmente 'arroyo de cenizas'). Encuentra una semejanza con Brujas la muerta: la visita de la ciudad se encuentra condicionada, sino motivada (como en el caso de Hugues) por el luto de su viudez. Hay una correspondencia entre la decadencia invernal de la ciudad y la del alma del protagonista. Asimismo, una vez instalado en la ciudad, el calor sofocante del verano, junto con la llegada del siroco, otorga una atmósfera de putrefacción a la ciudad: "Un siniestro bochorno oprimía las callejas; el aire era tan espeso que los olores provenientes de las casas, tiendas y fondas -vaharadas de aceite, nubes de perfume y muchos otros- flotaban inmóviles, sin disiparse" (Mann 1986: 64). La ciudad, ya sea en la melancolía invernal o en sofocante calor veraniego, ofrece una atmósfera opresiva, símbolo del callejón sin salida, estético y existencial, en el que se encuentra su protagonista, alejado del vitalismo.

En los dos clásicos del tema simbolista de la ciudad muerta, Brujas, la ciudad muerta y Muerte en Venecia, el espacio urbano 'sugiere' (he aquí el carácter expresivo, no conceptual, del símbolo) el alma adolorida, atormentada, de sus respectivos protagonistas.

\section{Tipología de pueblos abúlicos españoles en las novelas de Azorín}

Azorín, al enumerar en 1913 el programa de la Generación del 98 en el famoso artículo del mismo nombre, declara que este grupo, en el que debe incluirse, "ama los viejos pueblos" (1999: 210). Desde hacía algunos años ya venía representando estos pueblos y urbes desde el simbolismo de la ciudad muerta. No sólo se ocupaba de las poblaciones castellanas, manchegas o levantinas. Ocasionalmente, la Andalucía interior, montañosa, también se incorporaba a su visión personal del topos.

Las descripciones de Azorín son 'pictóricas', es decir, plásticas: describen verbalmente los espacios sociales mediante la traducción de signos plásticos (formas, texturas y colores). Así se establecen relaciones o vínculos entre la funcionalidad asignada al cuadro verbal, como procedimiento descriptivo, y el cuadro pictórico. De hecho, el cuadro descriptivo tiene por intención crear una imagen mental del espacio en el lector. Prieto de Paula (2006) utiliza el término cuadro rural para referirse a la descripción del pueblo que se realiza en Un pueblecito (Riofrío de Ávila), de la compilación España (1909), y creo que es un término acertado para nombrar el procedimiento que utiliza Azorín al describir los espacios humanos y arquitectónicos de las ciudades muertas o pueblos abúlicos. El cuadro urbano asume, en su enunciación, el punto de vista de un personaje testigo o de un narrador omnisciente hacia los espacios, públicos y privados. El cuadro rural cumpliría la misma función.

Diversos son los espacios arquitectónicos paradigmáticos de la ciudad muerta o pueblo abúlico: los conventos, como los que se describen en Don Juan ${ }^{6}$, en La voluntad o en 
la colección de ensayos El alma castellana, las iglesias y las casas tradicionales (descritas con más o menos detenimiento en todas sus novelas). En pocas ocasiones utiliza Azorín, imbricado con el topos del pueblo abúlico, el de las ruinas. En una de las escasas oportunidades en las que aparece, expresa el dominio del transcurso sosegado del tiempo sobre los objetos y los intereses humanos, aportado por el topos de la fuente, como ocurre en Doña Inés ${ }^{7}$.

La colección de ensayos España nos ofrece diversas manifestaciones de la ciudad muerta o pueblo abúlico, como "Horas de Sevilla", "Horas de Córdoba", "Horas de León", "La poesía de Castilla", "El apañador" y "El melcochero", según confirman Lamiquiz (1973) y Lozano Marco (2000: 25). Si realizamos un análisis comparativo de todos estos ensayos, se puede demostrar la utilización de los mismos estilemas en la descripción de las diversas ciudades muertas y pueblos abúlicos. El léxico que Lamiquiz (1973) identifica en los ensayos dedicados a las calles, callejuelas, las casas, los patios de las casas y catedrales, el cielo y el ambiente de Córdoba y Sevilla es, incluso, el mismo que podemos encontrar en sus novelas: estrechas, laberínticas, escasez de transeúntes, humildad, reposo, silencio, contemplación...

Podemos, asimismo, identificar dos funciones ideológicas en la representación de las ciudades y pueblos abúlicos en la novelística de Azorín. Por una parte, se observa el aprecio tradicionalista del narrador hacia los pueblos abúlicos. Por otra, el rechazo del narrador hacia el carácter carpetovetónico, primitivo, de estos pueblos y sus habitantes, en donde impera la brutalidad. Complementariamente, el narrador también puede apreciar en otras oportunidades, desde una perspectiva regeneracionista, al lento despertar de unos pueblos que pretenden integrarse en la modernidad (Pretel o Villena en Antonio Azorín).

\subsection{El tradicionalismo de los pueblos abúlicos}

Las dos ciudades muertas paradigmáticas en la prosa de Azorín son Toledo y Yecla, pero es la primera la que se encuentra más revestida de valores positivos, sobre todo de los místicos. Son conocidas las descripciones de la ciudad 'imperial' en Diario de un enfermo (1901) y La voluntad (1902). Observado por los narradores en su deambular callejero, en ambas aparece el famoso episodio del paso del pequeño ataúd, cuyo destinatario es un niño muerto, símbolo de la muerte metafórica -inactividad, silencio- que reina en la ciudad. Es un episodio que forma parte de Diario de un enfermo (entrada del 19 de noviembre, 10 de la noche) y del capítulo IV de la II parte de La voluntad, en ambos casos de Azorín, aunque también se incorpora en el capítulo XXX de la novela Camino de perfección, y en el artículo "Domingo en Toledo" (1901), en ambos casos de Pío Baroja ${ }^{8}$.

¿Qué simbología expresa Toledo para la intelectualidad fin de siglo? Ante todo, una de tipo místico: "Su vida histórica ya extinta sigue señalando el camino de lo que para el creyente -o el que quiera serlo- es la verdadera vida", señala Hinterhäuser (1980: 52) al referirse al poder de atracción que ejerce sobre los personajes Ángel Guerra (de la novela homónima de Galdós), Fernando Ossorio (Camino de Perfección, Pío Baroja) y Azorín (La voluntad, José Martínez Ruíz -Azorín-). En personajes que sufren una crisis nihilista, la ciudad mística se considera como una guía espiritual. El personaje desilusionado con el cientificismo y el progreso, imperante en la ideología española hegemónica del momento, se acercará al simbolismo místico, en particular, al sentimiento religioso de la Contrarreforma. En última instancia, la atracción hacia Toledo y su aura mística forma parte de las corrientes espirituales que dominaron el fin de siglo europeo. Toledo, así como las ciudades muertas que tuvieron un espléndido pasado político, artístico y espiritual, es el espacio con el que el sujeto 
artista, a su vez con aspiraciones espirituales, y asimismo desencantado del materialismo, se siente identificado. El artista, que se considera despreciado por los valores mercantilistas de la sociedad capitalista, aprecia y considera como 'compañero espiritual' a un espacio urbano que estos mismos procesos de la modernidad han condenado al olvido.

La simpatía tradicionalista hacia las ciudades o pueblos abúlicos también se observa en las descripciones de Segovia en Doña Inés. Se trata de una ciudad telúrica, tanto en términos literales (casas firmemente asentadas en el suelo) como metafóricos (ciudad cuyas raíces se extienden hasta las profundidades de la historia). En la ciudad muerta de Segovia dominan las arquitecturas eclesiásticas y monárquicas, símbolos de un poder social ya desaparecido pero que pervive a nivel espiritual en la conciencia de sus habitantes, así como del intelectual que radica en ella: "En el azul del cielo -sobre el amontonamiento de las viviendas- resaltan lo amarillo de la torre de la catedral y lo ceniciento de las techumbres del alcázar" (1997: 26).

Una táctica muy común en toda la obra de Azorín es, en el marco global de la descripción de la ciudad decadente, actualizar el esplendor económico que vivió en pasados siglos. Por ejemplo, en Doña Aña, con el uso del presente histórico, se emprende una descripción de la prosperidad económica que vivió Segovia a partir de la lana y el lino: "La ciudad resuena con el ruido de los telares" (Azorín 1997: 27). Son casos de analepsis, de saltos en el tiempo hacia atrás. Seguidamente, elige el narrador diversos momentos históricos -todos ellos en presente histórico- que le permiten ir describiendo la evolución económica, social y cultural de la ciudad. Azorín emplea esta técnica en diversas ocasiones, como también ocurre en el cuento Una ciudad y un balcón. En el caso de Segovia, en Doña Inés, después de la analepsis inicial, el narrador describe seguidamente cómo, paulatinamente, la ciudad castellana entra en declive económico (siglo XVIII):

\footnotetext{
El tiempo se va deslizando. El espeso enjambre de manos clarea. Muchos de los ricos lanificios se han cerrado; el estrépito de los telares se va asordando. Se han desplomado cuatro, seis u ocho casas en una callejuela; han arrancado las puertas y las ventanas y se las han llevado. Diez o doce de las treinta parroquias han sido clausuradas. El torbellino de las manos es más lento. (Azorín 1997: 28)
}

Un ejemplo de ciudad o pueblo abúlico sujeto a un declive progresivo se representa en Don Juan. Sólo se le nombra con el sintagma una pequeña ciudad, en el capítulo El espíritu de la pequeña ciudad. Introducida mediante una Guía de 1845, es una ciudad en decadencia que tuvo un pasado nobiliario espléndido, donde los oficios religiosos todavía forman parte de las escasas señales de vida que se pueden observar:

\footnotetext{
De noche, en las callejuelas, por las plazoletas, una voces largas cantan la hora, después de haber exclamado: “Ave María purísima!” Brilla un farolito en un retablo. No sabemos a dónde vamos a salir por esta maraña de callejitas oscuras. Vemos, a la débil claridad del cielo, que un viejo palacio tiene un sobrado en arcos, como una galería, debajo de un ancho alero. (2002: 40)
}

Por lo general, en las descripciones de Azorín, la época que más caracteriza el declive de las actividades económicas de las ciudades es el siglo XVIII.

\subsection{El regeneracionismo y los pueblos abúlicos: la crítica hacia la mentalidad carpetovetónica y el aprecio hacia los tímidos progresos de entrada en la modernidad}

La ciudad por antonomasia en las novelas de Azorín, en todo caso, no es Toledo sino Yecla. No sólo se describe en La voluntad, sino también en Las confesiones de un pequeño 
filósofo, exactamente en el Capítulo XIV, titulado precisamente Yecla. Frente a la primera novela, en la segunda la descripción y evaluación de este pueblo abúlico es más pesimista, cercana al tópico de la España negra, con sus pueblos 'primitivos'. Aunque el narrador aprecia en ella la pervivencia de las costumbres tradicionalistas, con toda su cultura material, también queda radiografiada como un pueblo carpetovetónico, donde el peso de la Muerte está determinado por la dureza de un medio físico implacable. En Las confesiones de un pequeño filósofo el narrador declara: "'Yecla -ha dicho un novelista- es un pueblo terrible.' Sí que lo es; en este puedo se ha formado mi espíritu. Las calles son anchas, de casas sórdidas o viejos caserones destartalados; parte del poblado se asienta en la falda de un monte yermo" (Azorín 1968: 51). En la Yecla de esta última novela ya no hay lugar para las tradicionales casas aseadas que encontramos en otras ocasiones. El tiempo cronológico no se materializa en indicadores laborales, sino religiosos. La religión puntúa el paso de las monótonas horas por medio de las campañas: "En la ciudad hay diez o doce iglesias; las campanas tocan a todas horas" (1968: 51). Son numerosísimas las menciones a las campanas en la prosa de Azorín, símbolo de amortajamiento, de ausencia de vitalismo, recurso que comparte con la prosa de Rodenbach. Asimismo, la muerte, en un espacio donde la juventud está ausente, es un suceso cotidiano: "Y de cuando en cuando discurre por las calles un hombre triste que hace tintinear una campanilla, y nos anuncia que un convecino nuestro acaba de morirse" (1968: 51).

Otro caso de ciudad o pueblo abúlico es Lantigua, de Diario de un enfermo, que se describe lacónicamente en la novela: "Lantigua es un poblachón manchego, triste, sombrío, tétrico" (Azorín 2000: 228). Para Martín "constituye una anticipación de la Yecla de La voluntad" (2000: 102).

También se representa un pueblo abúlico en Don Juan, en particular en su capítulo XIV, titulado "Un pueblo". Destacan dos cortas descripciones. La primera se dedica a enumerar la arquitectura religiosa, única huella de su pasado esplendor histórico, y las escasas instituciones eclesiásticas todavía activas, representativas de su letargo económico: "Hay en el pueblo una iglesia. Cuenta la iglesia con cuatro beneficios, un curado, tres beneficios simples, seis prestameras, un cabildo con veinte clérigos. Existen también en el pueblo tres capellanías; un monasterio de monjas con 40 religiosas y cuatro capellanías, y un convento de frailes con 20 religiosos" (Azorín 2002: 60). La segunda descripción, amparándose en un informe agrícola, Información sobre la crisis agrícola (1887), se apoya en la crítica regeneracionista ${ }^{9}$, al destacar el deplorable estado de la agricultura de los alrededores del pueblo y las pésimas condiciones sociales del campesino ${ }^{10}$.

El regeneracionismo no sólo implica la crítica de los pueblos carpetovetónicos, sino también el aprecio de los que transitan, tímidamente, hacia el progreso tecnológico. Predominan en Antonio Azorín ${ }^{11}$. Pretel, pueblo monótono y reposado ${ }^{12}$, se integra poco a poco en la vida moderna, modelo de regeneracionismo exitoso. Es un símbolo de una manera de entender España, la que se incorpora progresivamente a la modernidad. También es el caso de ciudad de Monóvar, tranquilo pero industrioso pueblo (Azorín 1998: 73-74), o el de Villena ${ }^{13}$. Otro ejemplo es Elda, aunque el narrador critica que sus obreros se encuentren condenados a sufrir un trabajo mecánico, alienante ${ }^{14}$. Por el contrario, claramente pueblo abúlico que no ha conocido ningún tipo de regeneracionismo económico es Torrijos, que vive del trigo y la aceituna, en Antonio Azorín. El narrador lo declara taxativamente: "Torrijos es el prototipo de los pueblos castellanos muertos" (1998: 198). 


\section{La ciudad muerta en la tradición de la literatura española}

Distinguible del motivo barroco de la poesía de ruinas, en la literatura española se pueden ubicar bastantes representaciones de ciudades o pueblos muertos, tanto en las últimas décadas del siglo XIX como en las primeras del XX.

Es el caso de la italiana Ligura de la Sonata de primavera (1904), de Valle-Inclán. De todas sus Sonatas es la que más claramente perfila, desde el marco de la estética decadentista, el topos de la ciudad muerta. Las calles vacías y los grupos de ancianas viudas y beatas que organizan su vida, día tras día, al compás de las misas, son atributos típicos de las ciudades muertas que aparecen ya desde la primera descripción de la ciudad de Ligura ${ }^{15}$. Es interesante el símil de las viejas que se asemejan sombras: se quiere significar que se encuentran más en el reino de los muertos que en el de los vivos y que la vieja ciudad es su materialización más pertinente. La anciana viuda vestida de negro es símbolo de muerte, entendida esta última como tiempo detenido, con exclusión de cualquier noción de progreso histórico. Aunque los acontecimientos de esta pequeña novela se desarrollan en pleno siglo XIX, la cultura y la sociedad estamental de la ciudad italiana, con claras reminiscencias dieciochescas, todavía se estructura a partir del Ancien Régime. Las relaciones de sociabilidad se rigen por las reglas y normas de la sociedad cortesana, tal como las describe Norbert Elias en La sociedad cortesana y El proceso de la civilización, o a nivel ficcional Balzac, en la Angulema de Las ilusiones perdidas. La Iglesia domina en Ligura, tanto en las prácticas rituales (procesiones, misas), como en su arquitectura (conventos, iglesias). Y, al igual que en las novelas de Azorín, las principales dimensiones sonoras de Ligura son el silencio y el sonido de las campanas: "Todas las campanas de la histórica ciudad doblaban a un tiempo" (Valle-Inclán 1990: 37); "Daba las doce el viejo reloj de la Catedral y cada campanada, en el silencio del jardín, retumbó con majestad sonora" (1990: 47).

En la poesía postromántica también se encuentra el topos que nos ocupa. Aparece en el poema "Santa Escolástica", de En las orillas del Sar, de Rosalía de Castro, donde se retrata a Santiago de Compostela como ciudad muerta ${ }^{16}$.

Este topos también lo utilizará Gómez Carrillo al describir a Santiago en su volumen Vistas de Europa, en la crónica "En Galicia": "Hoy, por desgracia, para las almas piadosas, Santiago entero es un sepulcro de palacios, de torres y de pórticos" (1919: 124). Al margen del progreso tecnológico, se ha convertido en 'museo' para turistas. En este tipo de ciudades, el flâneur Gómez Carrillo, como hará páginas después en la crítica dedicada a Venecia, se dedica a comparar el orgulloso y pomposo vitalismo del pasado con la indolencia del presente, a partir de la observación de la herencia arquitectónica: "Varias horas llevamos recorriendo la calles. A cada momento algún pórtico blasonado, alguna tapia carcomida, algún ventanal labrado, alguna columnata incompleta, nos hace detenernos para admirar los vestigios del esplendor antiguo de la metrópoli gallega" (1919: 124-5).

La poesía de Antonio Machado, sobre todo la de Campos de Castilla, cuenta con algunas descripciones de pueblos abúlicos, valorados desde la subjetividad del yo lírico. Así ocurre en “Orillas del Duero”: “Castilla, tus decrépitas ciudades!” (1998: 56), o en "Campos de Soria”:

¡Soria fría, Soria pura, / cabeza de Extremadura, / con su castillo guerrero/arruinado, sobre el Duero; / con sus murallas roídas / y sus casas denegridas! / “ “Muerta ciudad de señores, / soldados o cazadores; / de portales con escudos/de cien linajes hidalgos, / y de famélicos galgos, / de galgos flacos y agudos, /que pululan / por las sórdidas callejas, / y a la medianoche ululan, / cuando graznan las cornejas! // “Soria fría! La campana / de la Audiencia da la una. / Soria, ciudad castellana / “itan bella! bajo la luna. (1998: 78-79) 
El yo-lírico llega a utilizar el sintagma 'muerta ciudad'. La arquitectura nos habla de pasados poderes medievales ya desaparecidos, cuando esta urbe era 'cabeza de proa' de la Reconquista cristiana ('castillo guerrero arruinado', 'murallas roídas'). Sus viviendas se desmoronan (casas denegridas, sórdidas callejas) y las campañas puntúan la monótona temporalidad cotidiana. En este poema, han desaparecido las limpias casas de Azorín, salvaguardas de la tradición.

Ilustres precursores del topos simbolista de la ciudad muerta también se encuentran en la novela realista-naturalista. Se puede definir como tal la otoñal Vetusta, en La Regenta, cuya humedad provoca la reclusión hogareña de sus habitantes (y de Ana Ozores en su intérieur burgués). El nombre Vetusta nos habla, simbólicamente, de la condición momificada, anquilosada, sobre todo moral, de esta ciudad. Es especialmente evidente la metáfora de la ciudad muerta al inicio del Capítulo XVIII:

La torre de la catedral aparecía a lo lejos, entre la cerrazón, como un mástil sumergido. La desolación del
campo era resignada, poética en su dolor silencioso; pero la tristeza de la ciudad negruzca, donde la humedad
sucia rezumaba por tejados y paredes agrietadas, parecía mezquina, repugnante, chillona, como canturia de
poder de solemnidad. Molestaba; no inspiraba melancolía sino un tedio desesperado. (Alas 2000: 607-608)

Como es típico en las representaciones de este topos, el dominio espiritual queda simbolizado por la omnipresencia de la catedral. Si algo comparte esta imagen otoñal de Vestusta con la Bruja de Rodenbach es la omnipresencia de la humedad y de las imágenes acuáticas (la torre de la catedral como mástil sumergido), que connotan muerte, inactividad, tedio... La propia Ana Ozores llega a la misma conclusión. Su voz nos llega desde el estilo indirecto libre:

¡Cuán difícil era admirar la creación para elevarse a la idea del Creador, en aquella Encimada taciturna, calada de humedad hasta los huesos de piedra y madera carcomida; de calles estrechas, cubiertas de hierba -hierba alegre en el campo, allí símbolo de abandono-, lamidas sin cesar por las goteras de los tejados, de monótono ruido acompasado al salpicar los guijarros puntiagudos...! (2000: 613)

Atributos típicos de la ciudad muerta aparecen en estas reflexiones de Ana Ozores: ausencia de Dios, abandono y decrepitud, soledad, la taciturnidad de la Encimada, el barrio más añejo de Vetusta...

Galdós ofrece dos ejemplos de pueblos abúlicos, Orbajosa, en Doña Perfecta, y Toledo, en Ángel Guerra. Dos pequeñas descripciones de Orbajosa nos confirman su condición de pueblo abúlico. En el Capítulo 12, Pepe Rey, el ingeniero que llega al pueblo con su pensamiento progresista, huye del tedio del Casino, espacio típico de la ciudad provinciana, y sale a la calle, "sombreada toda por la pavorosa catedral, que al extremo alzaba su negro muro carcomido" (2000: 497). De nuevo tenemos el dominio de la religión, simbolizado por la omnipresencia de la torre de la catedral. En el Capítulo 13, después de visitar la casa de las Troyas, Pepe Rey recorre las calles de Orbajosa. Es un pueblo grande de La Mancha, un poblachón (como los descritos posteriormente por Baroja), cuyo clima inhóspito determina la falta de vitalidad e incentiva la improductividad de sus habitantes (un nuevo caso de determinismo ambiental):

Visitó el mercado, la calle de Tripería, donde estaban las principales tiendas; observó los diversos aspectos que ofrecían la industria y comercio de la gran Orbajosa, y como no hallara sino nuevos motivos de aburrimiento, encaminóse al paseo de las Descalzas; pero no vio en él más que algunos perros vagabundos, porque con motivo del viento molestísimo que reinaba, caballeros y señoras se habían quedado en sus casas. Fue a la botica, donde hacían tertulia diversas especies de progresistas rumiantes, que estaban perpetuamente masticando un tema sin fin; pero allí se aburrió más. (2000: 505) 
Otros autores se ocuparon de reflexionar sobre Toledo en el marco de la simbología de la ciudad muerta. Está presente en El Greco y Toledo (1957), de Gregorio Marañón. Pero no sólo escritores españoles han dedicado comentarios a la ciudad de Toledo, sino también extranjeros, como el escritor francés Maurice Barrés, en su relato de viaje El Greco o el secreto de Toledo (1912).

Los pueblos abúlicos también aparecen en España negra (1898), libro en colaboración entre el poeta belga Émile Verhaeren y el pintor Darío de Regoyos. Tudela, Tarazona, Veruela y Sigüenza, en el viaje de este poeta y este pintor, son cuatro impresiones crepusculares retratadas desde parecida puesta en escena (1963: 56).

Pío Baroja también nos ofrece retratos de pueblos abúlicos. Nos ocupamos de sus dos novelas más famosas. Un ejemplo es Alcolea del Campo, de El árbol de la ciencia, sinécdoque de la abulia nacional. Es una ciudad carpetovetónica, caracterizada por costumbres bárbaras, atávicas. Queda representada desde el determinismo medioambiental. El clima implacable y una alimentación básicamente carnívora producen una población exaltada, embrutecida, primitiva: "Las costumbres de Alcolea eran españolas puras, es decir, de un absurdo completo. // El pueblo no tenía el menor sentido social; las familias se metían en sus casas, como los trogloditas en su cueva. No había solidaridad; nadie sabía ni podía utilizar la fuerza de la asociación" (2002: 167).

En Camino de perfección, este determinismo medioambiental también estructura la representación de Illescas, "que parecía dormido profundamente bajo un sol ardiente, abrasador; las puertas de las casas estaban cerradas" (Baroja 2005: 107). Este mismo punto de vista ideológico y estético se utiliza en Yécora, pueblo nuevo que, en lugar de mostrar el empuje vitalista de los valores de la modernidad, ha heredado el temperamento carpetovetónico de la sociedad rural: "Yécora es un pueblo terrible; no es de esas negrísimas ciudades españolas, montones de casas viejas [...]. Allí todo es nuevo en las cosas, todo es viejo en las almas [...]. Se respira en la ciudad un ambiente hostil a todo lo que sea expansión, elevación de espíritu, simpatía humana" (2005: 173-4).

Pero también encontramos en Baroja la representación de la tradicional ciudad muerta de tonalidad mística. En Camino de perfección es el caso de Toledo, cuyo ambiente moral, eclesiástico, determina el estado de ánimo moral de Fernando Ossorio, su protagonista. Su excitación mística se encuentra provocada por "las vibraciones largas de las campanas, el silencio y la soledad que iba a buscar por todas partes" (2005: 131).

Contemporáneo de Azorín es el poeta modernista Francisco Villaespesa, quien en su poema "Ciudad muerta", del libro Las horas que pasan (1902), representa los objetos y espacios más comunes en la descripción de este topos. De nuevo se distingue la mole de las torres de las iglesias. El mediodía (ni una sombra, ni una luz), junto con el atardecer, es uno de los momentos paradigmáticos. En el mediodía, cuando domina un sol implacable, los escasos habitantes se encuentran en las casas, tras las puertas cerradas. Por su parte, las calles vacías y silenciosas y las fuentes sin agua simbolizan la ausencia de toda renovación, de toda fertilidad:

\footnotetext{
¡Oh la ciudad sin vida, / la vieja ciudad muerta, / que la luna, como un abandonado / cementerio blanquea! / Las calles silenciosas. Como tumbas / son las calles. Las puertas, / las ventanas, cerradas... Ni una sombra, / ni una luz, ni una queja. / El musgo crece en las ruinosas plazas, / Las fuentes están secas. / El tiempo se ha dormido en los relojes / De las viejas iglesias, / Que en la noche la inmensa podredumbre / De sus moles fantásticas proyectan. / ¡Silencio secular, ciudad sin vida, / Elegía de piedra / Llorando el abandono de una raza, / Que a Dios orando, la rodilla en tierra, / Sintió sonar la triste campanada / De su hora postrera! / Oh la ciudad sin vida / la vieja ciudad muerta, / que la luna, como un abandonado cementerio blanquea! (García Pérez 2008: 127)
} 
El topos de la ciudad muerta, para pervivir a lo largo del siglo XX, ha debido resemantizarse. Como topos de tipo culturalista, no debe extrañar su aparición en la generación de los novísimos, que cultiva una estética de este talante. En Astrolabio (1975-1979), de Antonio Colinas, se incorpora el poema "La ciudad está muerta". Frente a descripciones previas, sobre todo de las españolas, queda resaltada más la estética de la descomposición corporal:

\begin{abstract}
¿No tuviste bastante con morir una vez / en la muerta ciudad, que vuelves otra vez / entre sus candorosos muros iluminados / a veces por verdores putrefactos? // Llueve, llueve y la música es negra en estas calles / abarrotadas de crucifijos que andan, de agonizantes que laboran, de insepultos cadáveres que aplauden y sonríen. (2011: 233)
\end{abstract}

Otro ejemplo es el poema "Unos soportales", de Andrés Trapiello, del poemario La vida fácil (1985). La descripción de la ciudad adopta la construcción del espacio desde el tópico del beatus ille, ideal para el retiro y la vida contemplativa y meditativa del intelectual:

Mi vida son ciudades sombrías, de otro tiempo. / Como se acerca una cacerola / para escuchar el mar, así por ellas / vago yo muchas tardes. / Ya no tienen farolas / con esa luz revuelta ni tampoco los coches / antiguos de caballos. Todavía conservan / sus negros soportales donde se huele a gato / y donde aún se abren misteriosos comercios / iluminados siempre con penumbra de velas. / Son ciudades levíticas, sin porvenir y tristes, / con cien zapaterías y tiendas de lenceros / cada cincuenta metros. Todas tienen conventos / con los muros muy altos donde crecen las hierbas, / jaramagos y cosas así. No son modernas, / pero querían serlo. Yo las recorro solo, / e igual que suenan olas en una cacerola, / así mis emociones me parecen eternas. (2007: 504)

Por lo demás, podría, en una futura investigación, investigarse el desarrollo del topos de la ciudad muerta en la narrativa escrita durante el franquismo, en novelistas como Carmen Martín Gaite o en Miguel Delibes. De alguna manera, la vida aprisionada y sin expectativas de la vida provinciana, expresada en los novelistas de esta generación, permitiría realizar una lectura alegórica sobre las restricciones existenciales impuestas por el régimen franquista.

En la literatura hispanoamericana también se puede rastrear la presencia de la ciudad muerta en el siglo XX. El escritor peruano Abraham Valdelomar cuenta con dos novelas breves en las que usa este topos, tituladas La ciudad de los tísicos (1911) y La ciudad muerta (1911). Por otra parte, en el poema "El solterón”, del poemario Los crepúsculos del jardín (1905), de Leopoldo Lugones, se representa la cotidianeidad hogareña de un solterón de una ciudad muerta, de claras resonancias rodenbachdianas, más que noventaiochistas, ya que la atmósfera es, básicamente, norteña, orientada hacia la reclusión:

Largas brumas violetas / Flotan sobre el cielo gris, / Y allá en las dársenas quietas / Sueñan oscuras goletas / Con un lejano país. // El arrabal solitario / Tiene la noche a sus pies, / Y tiembla su campanario / En el vapor visionario / De ese paisaje holandés [...] En el desolado río / Se agrisa el tono punzón / Del crepúsculo sombrío, / Como un imperial hastío / Sobre un otoño de gro. (Lugones 2008: 290, 294)

Según García Pérez (2008: 119-130) es un poema ecléctico que utiliza representaciones del tópico que ya circulaban en la época de su composición: la semántica del silencio (las calles silenciosas), el dominio tutelar de la religión, la quietud de las dársenas, la decadencia pasada y el amortajamiento actual, la soledad...

Un tópico asociado al de la ciudad muerta es el del jardín viejo, abandonado o muerto, según sea el caso, muy utilizado en la poesía modernista, como se ha encargado de demostrar García Pérez (2008), y que también ha analizado detenidamente Litvak (1979) desde el tópico de los jardines otoñales. 
Por otra parte, gran conocedor de la literatura simbolista, Gómez Carrillo adopta el tópico de la ciudad muerta y lo resemantiza para describir las ciudades destruidas por la I Guerra Mundial en El quinto libro de las crónicas, desde la retaguardia del frente de batalla belga. Iprès es una ciudad muerta por partida doble: es una urbe en decadencia y, además, ha sido arrasada por las bombas. El corresponsal guatemalteco dedica parte de su crónica a describir la atmósfera de Iprès como ciudad muerta antes de su destrucción en la I Guerra Mundial:

\footnotetext{
Iprès, como Toledo, era una noble población que dormía un sueño de glorias pasadas al abrigo de todas las ambiciones y de todas las convulsiones del tiempo... Iprès no acariciaba quiméricas esperanzas de poderío ni esplendor... Iprès era una bella del bosque durmiente que ningún príncipe debía sacar jamás de su lecho de piedra...Vestida de encajes góticos esperaba sin impaciencia el paso de los siglos, sin más ilusiones que las de agonizar lentamente, tranquilamente, rodeada del respeto de los hombres y del amor de los poetas. Sus campanas mismas tenían voces apagadas que parecían marcar horas ancianas y celebrar ceremonias desvanecidas. Su atmósfera gris, tibia, húmeda, sugería ideas de pereza meditativa y de dulce escepticismo. [...] esa misma humildad, ese mismo alejamiento de las fiebres modernas, parecían una garantía para su larga vejez tranquila... (1922: 139)
}

Iprès queda revestida de los clásicos atributos de la ciudad muerta simbolista: la ensoñación, el sosiego, el largo declive económico, la omnipresencia de un poder eclesiástico (igualmente agónico, en las innumerables iglesias) y de las campanas... Gómez Carrillo describe un caso de ironía situacional. Llega la guerra para rematar una ciudad que ya era moribunda desde hacía siglos: "en todas partes es la misma desolación, la misma tristeza, el mismo silencio sepulcral" (1922: 125). Pasa de ser una ciudad muerta metafórica a ser una ciudad muerta, literalmente, asolada por las bombas. Las campanas, símbolo supremo del adormecimiento de la ciudad muerta simbolista, son resignificadas o resemantizadas, hasta quedar convertidas en el único símbolo de vida de la ciudad destruida, que por lo demás sirve para destacar todavía más su desolación: "Hoy es el rumor de una campana lo único que anima el espacio, un rumor grave y suave que se extiende en el aire claro con una serenidad religiosa. ¿De qué campanario salvado por milagro viene?; ¿Qué mensaje lleva en sus alas hacia las aldeas vecinas?" (1922: 143).

Por último, podría considerarse la pertinencia de las ciudades coloniales del interior de Colombia, en las novelas de Gabriel García Márquez (por ejemplo, El amor en los tiempos del cólera), como variaciones del topos de la ciudad muerta.

\section{Conclusiones}

El topos de la ciudad muerta, en boga en las últimas décadas del siglo XIX y primeras del XX, pertenece a la estética simbolista. Sugiere el poder de la ensoñación, el estado alucinatorio del sujeto enunciador, la crisis de la noción de progreso histórico, en el caso belga. En Brujas la ciudad muerta, de Rodenbach, el poder de la religión sobre las costumbres de los habitantes es omnipresente, ya sea que incentive el sentimiento de luto o, alternativamente, el sentimiento de culpa de su protagonista. Se aprecia una sintonía entre su estado de ánimo y la atmósfera de la ciudad, así como la opresión moral que, en ocasiones, ejercen los símbolos religiosos de la ciudad en su alma.

En cambio, en la escritura de Azorín, la atmósfera religiosa no determina directamente el estado de ánimo de los protagonistas de sus novelas. Esta atmósfera forma parte, más bien, de un medio social que se encuentra en sintonía con el retiro al que aspiran personajes como Antonio Azorín, después de rechazar el compromiso político previamente asumido en la ciudad. 
Como símbolo ambivalente, en el caso español, hablamos de su empleo en el marco de una defensa de los valores tradicionales del 'alma nacional', o de una crítica regeneracionista a la incapacidad de renovar materialmente (las instituciones y la economía) la vida española. Las representaciones españolas de la ciudad muerta (ciudades y pueblos abúlicos) carecen de la tonalidad alucinatoria, ensoñadora, que aparecen en diversas representaciones europeas, sobre todo flamencas.

Son numerosos los pueblos muertos o abúlicos en las novelas de Azorín. Yecla aparece en La voluntad y Las confesiones de un pequeño filósofo; Lantigua, en Diario de un enfermo; Toledo, en La voluntad y Diario de un enfermo; Torrijos, Monóvar y Pretel, en Antonio Azorín.

Pero la ciudad muerta, como topos, se extiende más allá del movimiento simbolista y de sus manifestaciones textuales y se expresa en el marco de otros movimientos estéticos. En la estética del realismo (en ocasiones, realismo naturalismo) son ciudades muertas Vetusta (La Regenta, Clarín), Toledo (Ángel Guerra, Benito Pérez Galdós) u Orbajosa (Doña Perfecta, Benito Pérez Galdós), mientras que en la crónica periodística modernista se perfilan desde este símbolo la española Santiago de Compostela o la belga Iprès (El quinto libro de las crónicas, Gómez Carrillo). Asimismo, el realismo social español de los años cincuenta y el realismo mágico hispanoamericano han representado este topos y lo han investido de una semántica específica (la representación de un sistema dictatorial, en el primer caso, y la contrapartida mortuoria del interior montañés frente al espacio exuberante de la costa, en el segundo).

\section{Notas}

1. Este concepto procede del libro Andalucía trágica, de José Martínez Ruiz.

2. Este concepto procede de Darío de Regoyos y de Émile Verhaeren, España negra. 1963. Madrid: Taurus.

3. Así, podemos ofrecer como ejemplo, el topos de la luz como arma, rastreable desde los tiempos bíblicos hasta la actualidad (López Martínez 2007).

4. También en el discurso cinematográfico encontramos directores que han asignado un gran protagonismo al espacio urbano, incluso desde su homología con la psique humana de los personajes que lo transitan. Así, por ejemplo, Michel Angelo Antonioni en su trilogía La aventura, El eclipse y El desierto rojo, habla de la desorientación existencial de una mujer de la alta burguesía italiana en unas calles, las milanesas, de 'fría' arquitectura racionalista...

5. Durante este rito, las campanas cumplen un papel relevante: "y las campanas envejecidas, las extenuadas, las abuelillas con bastón, las campanas de los conventos, de las viejas torres, hogareñas, valetudinarias, que durante el resto del año no pronuncian palabra, caminan y siguen el cortejo durante la procesión de la Semana Santa (todas parecían llevar, bajo sus ropas de bronce gastado, festivas sobrepellices blancas, telas plisadas como un abanico)" (Rodenbach 2011: 106).

6. "En la actualidad, hay en la pequeña ciudad dos conventos de frailes y cuatro de monjas. De los dos conventos de frailes, uno es de franciscanos, el otro, de dominicos. Los conventos de monjas son: el de las Jerónimas, el de las Capuchinas de la Pasión, el de las Dominicas y el de las Carmelitas descalzas" (Azorín 2002: 41).

7. "Si nos llegáramos hasta el cercano monasterio del Parral, en ruinas, con los techos desfondados, con las estancias llenas de escombros, con las vides labruscas enroscadas a los maderos carcomidos, escucharíamos en un apartado aposento caer en un pilón el chorro de una fuente y al mismo tiempo, como réplica este murmurio, en lo hondo, en un subterráneo, el son pausado, intercadente, del agua que se entrederrama, que se derrama despacio, con lentitud" (Azorín 1997: 67).

8. Martín considera que el "episodio del ataúd blanco debió ser un hecho real que llamó la atención de los dos amigos [J. Martínez Ruíz -Azorín- y Pío Baroja], pues ambos lo han trasladado a la literatura con una notable coincidencia de detalles" (2000: 207). 
9. La crítica regeneracionista radica en la crítica de la situación de la economía del espacio rural, en la crítica de 'España como problema'.

10. "La clase proletaria de alimenta de patatas, judías, chiles y acelgas; todo ello «sin pan». El suelo es pobre. Con los cereales que se producen «apenas hay para atender al consumo de la localidad». Van desapareciendo los viñedos, a causa «del empobrecimiento del agricultor, que no tiene para renovar las vides, que se mueren de viejas, y no puede poner de nuevo»" (Azorín 2002: 61).

11. Los valores que, según Prieto de Paula, se expresan en la novela de Antonio Azorín sobre los pueblos castellanos y manchegos, son siempre negativos, a igual que los expresados en la Yecla de La voluntad: "incuria, sequía, falta de sentido práctico, catolicismo intransigente y asfixiante, atracción por la muerte, resignación, suciedad, odio a los árboles y a la luz, sollozos, intolerancia, crueldad agresiva” (2006: 188). Mi lectura de las ciudades de la novela Antonio Azorín es parcialmente diferente a la propuesta por Prieto de Paula.

12. "hay casas viejas con balcones de madera tosca, y casas modernas con aéreos balcones [...] La iglesia es de piedra blanca [...] Y un viejo reloj lanza de hora en hora sus campanadas graves, monótonas" (Azorín 1998: 118).

13. "Esta es una ciudad vetusta, pero clara, limpia, riente. Tiene callejuelas tortuosas que reptan monte arriba; tiene vías anchas sombradas de plátanos; tiene viejas casas de piedra con escudos y balcones voladizos; tiene una iglesia con filigranas del Renacimiento, con una soberbia reja dorada, con una torre puntiaguda; tiene una plaza donde hay un hondo estanque de aguas diáfanas que las mujeres bajan por una ancha gradería a coger en sus cántaros; tiene un castillo que aún conserva la torre de homenaje, y cuyos salones don Diego Pacheco, gran protector de los moriscos, vería ondular el cuerpo serpentino de las troteras" (142).

14. "Elda es un pueblo activo. La agricultura no basta para su vida: ha nacido la industria. Y es una sola industria, que hace trabajar a todos los obreros en lo mismo, que los conforma con iguales aptitudes, que mueve toda la actividad del pueblo en una orientación idéntica" (Azorín 1998: 115-116).

15. Así, por ejemplo, el cascabeleo de las mulas encuentra un eco "en las calles desiertas donde crecía la yerba. Tres viejas, que parecían sombras, esperaban acurrucadas a la puerta de una iglesia todavía cerrada, pero otras campanas distantes ya tocaban a la misa de alba. La silla de posta seguía una calle de huertos, de caserones y de conventos, una calle antigua, enlosada y resonante" (Valle-Inclán 1990: 5).

16. Al ser un poema largo, y ya que no queda sometido a análisis, se ha decidido situarlo a pie de página: "Una tarde de abril, en que la tenue / llovizna triste humedecía en silencio / de las desiertas calles las baldosas, / mientras en los espacios resonaban / las campanas con lentas vibraciones, dime a marchar huyendo de mi sombra. [...] Soplo mortal creyérase que había / dejado el mundo sin piedad desierto, / convirtiendo en sepulcro a Compostela. / Que en la santa ciudad, grave y vetusta, / no hay rumores que turben importunos / la paz ansiada en la apacible siesta. // ¡Cementerio de vivos! -murmuraba / yo al cruzar por las plazas silenciosas / que otros días de glorias nos recuerdan. / ¿Es verdad que hubo aquí nombres famosos, / guerreros indomables, grandes almas? / ¿Dónde hoy su raza varonil alienta? / [...] Después la catedral... palacio místico / de atrevidas románicas arcadas / y con su Gloria de bellezas llena. / Me pareció al mirarla que quería/ sobre mi frente desplomar, ya en ruinas, / de sus torres la mole gigantesca. / [...] Atrás quedaba aquella calle adusta, camino de los frailes y los muertos, siempre vacía y misteriosa siempre, / con sus manchas de sombra gigantescas / y sus claros de luz, que hacen más triste / la soledad y que los ojos hieren. // Y en tanto... la llovizna, como todo / lo manso cerca, sin cesar regaba / campos y plazas, calles y conventos / que iluminaba el sol con rayo oblicuo / a través de los húmedos vapores, / blanquecinos a veces, otras negros. // Ciudad extraña, hermosa y fea a un tiempo, / a un tiempo apetecida y detestada, / cual ser que nos atrae y nos desdeña. / Algo hay en ti que apaga el entusiasmo, / y del mundo feliz de los ensueños/a la aridez de la verdad nos lleva" (Castro 2003: 296-298).

\section{Bibliografía}

Bajtín, Mijaíl. 1986. Problemas literarios y estéticos. México: Alianza.

Baroja, Pío. 2002. El árbol de la ciencia. Madrid: Alianza. 
2005. Camino de perfección. Madrid: Alianza.

Berg, Christian; Durieux, Frank y Geert Lernout (Eds.). 1995. The turn of the Century. Le tournant du siècle. Modernism and Modernity in Literature and the Arts. Le modernism et la modernité dans la literature et les arts. Berlin: Walter de Gruyter.

Castro, Rosalía de. 2003. Poesía. Madrid: Alianza.

Clarín, Leopoldo Alas. 2000. La regenta. Madrid: EDAF.

Cuvardic García, Dorde. 2009. "El debate Modernismo-Generación del 98”. Reflexiones. 88 (2): 101-112.

Friedman, Donald Flanell. 1990. The symbolist dead city. A Landscape of Poesis. New York: Garland.

García Pérez, Rafael. 2008. "Interpretaciones del tópico de la ciudad muerta en la poesía española y francesa". Cédille. Revista de estudios franceses. 4: 119-130.

Gleber, Anke. 1995. "The Secret Cities of Modernity: Topographies of Perception in Georges Rodenbach, Robert Walser, and Franz Hessel”. En: Berg et al. (Eds.), 363-379.

Gómez Carrillo, Enrique. 1919. Obras completas. Tomo IV. Vistas de Europa. Madrid: Mundo Latino. 235-254.

1922. El quinto libro de las crónicas. Madrid: Mundo Latino.

Gorceix, Paul. 1992. Reálités flamandes et simbolisme fantastique. Bruges-la-Morte et Le Carilloneur de Georges Rodenbach. Paris: Lettres Modernes.

Hinterhäuser, Hans. 1980. Fin de siglo: Figuras y mitos. (Trad. María Teresa Martínez). Madrid: Taurus.

Lamiquiz, Vidal. 1973. Ciudades en Azorín. De León por Córdoba a Sevilla. Interpretación semántico-estilística. Sevilla: Anales de la Universidad Hispalense. Publicaciones de la Universidad de Sevilla.

Langer, Peter. 1984. "Sociology-Four images of organized diversity: bazaar, jungle, organism, and machine". En: Rodwin y Hollister (Eds.), 97-117.

Litvak, Lily. 1979. Erotismo fin de siglo. Barcelona: Bosch.

2011. "Hacer visible lo invisible. El Simbolismo en la pintura española del paisaje, 1891-1930". Magazine Modernista. Revista digital para los curiosos del modernismo. http://magazinemodernista.com/2011/05/09/hacer-visible-lo-invisible-el-simbolismoen-la-pintura-espanola-del-paisaje-1891-1930.

López Martínez, María Isabel. 2007. El tópico literario: teoría y práctica. Madrid: Arco.

Lotman, Iuri. 1996. "El símbolo en el sistema de la cultura". La semiosfera I. Madrid: Cátedra. 143-156.

Lozano Marco, Miguel Ángel. 2000. Imágenes del pesimismo. Literatura y arte en España. 1898-1930. Alicante: Universidad de Alicante.

Lugones, Leopoldo. 2010. “El solterón”. En: Serna y Castany (Eds.), 290-296.

Machado, Antonio. 1998. Campos de Castilla. Madrid: Biblioteca Nueva. 
Mann, Thomas. 2005. Muerte en Venecia. Barcelona: Edhasa.

Martín, Francisco J. 2000. “Introducción”. En: José Martínez Ruiz (Azorín). Diario de un enfermo Diario de un enfermo. Madrid: Biblioteca Nueva.

2003. Las novelas de 1902. Sonata de Otoño, Camino de Perfección, Amor y pedagogía, La voluntad. Madrid: Biblioteca Nueva.

Martínez Ruíz, José (Azorín). 1968. Las confesiones de un pequeño filósofo. Madrid: EspasaCalpe.

1996a. Castilla. Madrid: EDAF.

1996b. La voluntad. Madrid: Biblioteca Nueva.

1997. Doña Inés. Historia de amor. Madrid: Acento.

1998. Antonio Azorín. Madrid: Biblioteca Nueva.

1999. Lecturas españolas. Clásicos y modernos. Al margen de los clásicos. México: Porrúa.

2000. Diario de un enfermo. Madrid: Biblioteca Nueva.

2002a. El alma castellana (1600-1800). Madrid: Biblioteca Nueva.

2002b. Don Juan. Madrid: Biblioteca Nueva.

Naupert, Cristina. 2001. La tematología comparatística. Entre teoría y práctica. Madrid: Arco.

Ortega y Gasset, José. 1957. “Azorín o primores de lo vulgar”. Obras completas. Tomo II. El espectador (1916-1934). Madrid: Revista de Occidente.

Pérez Galdós, Benito. 2000. Miau. Misericordia. Doña Perfecta. Madrid: Edimat.

Peyraga Pascale (Coord.). 2009. Los retratos de Azorín: en la encrucijada de unas subjetividades. Instituto de Cultura Juan Gil Albert.

Pike, Burton. 1981. The Image of the City in Modern Literature. Princeton: Princeton University Press.

Prieto de Paula, Ángel. 2006. Azorín frente a Nietzsche y otros ensayos noventayochistas. Alicante: Aguaclara.

Regoyos, Darío y Émile Verhaeren. 1963. España negra. Madrid: Taurus.

Rodenbach, Georges. 1930. Poesías. Barcelona: Cervantes. 2011. Brujas la muerta. Madrid: Vaso Roto.

Rodwin, Lloyd y Robert M. Hollister (Eds.). 1984. Cities of the mind. Images and themes of the city in the social sciences. New York: Plenum.

Sanz Pastor, Marta. 2007. Metalingüísticos y sentimentales. Antología de la poesía española (1966-2000). 50 poetas hacia el nuevo siglo. Madrid: Biblioteca Nueva.

Serna Arnaiz, Mercedes y Bernat Castany Prado (Eds.). 2010. Antología crítica de poesía modernista hispanoamericana. Madrid: Alianza. 
Shaw, Donald L. 1997. La generación del 98. Madrid: Cátedra.

1998. "More about Abulia". ALEC. 23: 451-464.

Valle-Inclán. 1990. Sonata de primavera. Sonata de estío. Sonata de otoño. Sonata de invierno. México: Porrúa.

Verhaeren, Emile y Darío de Regoyos. 1963. España negra. Madrid: Taurus.

Vigneron, Denis. 2009a. “Azorín et Darío de Regoyos; une sensibilité de l'Espagne à l'unisson”. En: Peyraga (Coord.), 121-138.

2009b. La création artistique espagnole à l'épreuve de la medernité esthétique européenne (1898-1931). Paris: Publibook. 